\title{
Contemporary North Caucasian Romance Myth in the Context of World Literature
}

\author{
Kutas Nukhovna Paranuk \\ Kirill Nikolaevich Ankudinov \\ Uchuzhuk Maskhudovich Panesh
}

Fatimet Nurbievna Kerasheva

Federal State Budget Institution of Higher Professional Education «Adyghe State University» (ASU) 385000, Maikop, street Pervomayskaya, 208, Russian Federation; Email: nisadgu@yandex.ru

\section{Doi:10.5901/mjss.2015.v6n5s2p259}

\section{Abstract}

The article deals with the North Caucasian romance myth of the past three decades in the context of neo-mythologism in the world literature. The purpose of the article is to identify the origin of the North Caucasian romance myth, its mythoephic background, nature and mythologism types. To analyze the problems of myth, folklore and literary relationships in the North Caucasian romance and to identify philosophical and psychological aspects of myth-making by North Caucasian writers we use both folklore and literary aspects and the achievements of psychoanalytic, structural and semiotic approaches. In the Introduction, the theoretical aspects of the problem under study of the romance myth genre from the perspective of the neomythologism actualization, the state of the previous study of the problem both in domestic literary criticism and foreign literary research. The bulk of the article is devoted to the analysis of the impact of mythopoetics on the semantics and artistic structure of the contemporary romance myth. During the sequential analysis of romance myths by North Caucasian writers such as $H$. Beshtokov, M. Bulkaty, N.Dzhusoyty, Yu.Chuyako, D. Koshubaev, N. Kuyeko both common patterns that are typical of their myth making and individual artistic features are considered. In particular, the functional significance of the myth in the contents and structure of romance myths, topic peculiarities, plot structure, image structure, world modeling are identified. The presence of mythopoetic chronotopes in all the romances under study, complex space-time continuum with a typical temporal change of plans and extent of spatial loci is marked. In the narrative texts of the novels under consideration the levels of mythopoetics are differentiated, the implicit nature of mythologism is traced. Such methods and techniques as intertextuality, allusion, reminiscence, code, symbol, myth, archetype, are marked as specific features of the literary text organization. Mythologism types of the works under consideration are identified; parallels between them and the Western European and American romance myth are drawn. In particular, the romance myths by M. Bulkaty "The Seventh Campaign of Soslan Narty", D. Koshubaev "Abrag", and H. Beshtokov "The Stone Age" are referred to a mixed type of mythologism and determined within the framework of post-modernism. The novel "The Wine of the Dead" by N. Kuyeko is considered in line with the "magic realism" and comports with the novel "One Hundred Years of Solitude" by G. Marquez. In conclusion it is stated that re-mythologizing the North Caucasian novel and modernization of classical mythology at the turn of XX-XXI centuries caused its certain transformation that has led to the expansion and deepening of its problematics and enriching the genre and stylistic forms. It is established that the myth making nature of modern North Caucasian writers correlates with the main trends of world literature and can be defined as neo-mythologism inherent in post-modernism and magic realism.

Keywords: neo-mythologism, romance, transformation, archetype, mythologem, reminiscences, allusion, post-modernism, magic realism

\section{Introduction}

Neo-mythologism became a feature of the entire world literature of the twentieth century. The literature came to such a level of modernization of classical mythology, which pointed to the re-mythologizing, mythopoetic "re-creation of ancient histories" and, finally, the myth-making, the creation of new myths that "meet the life making aspirations of changing literature" (Sarukhanyan 2002). According to N. Frye, to certain extent mythologism is a reaction to the rationalistic, scientific Worldview, pushes a man aside with its objectivity, depersonalization (Frye, 1976).

In the 80-90-ies of the twentieth century the tendency of attraction to neo-mythologism was clearly marked out in North Caucasian literatures, just another return and deeper penetration into the mythoepic sources. Neo-mythologism paradigm of the novel was justified by several reasons: the dialectic of the national and the universal, the desire to 
combine into a single stream the present with the past. The authors sought to overcome the boundaries of traditional subjects and to enter the large-scale artistic research of current global problems: war and peace, the man and the history, the man and nature. To solve such global problems there was nothing better than the myth, with its universal common to humanity meaning and holistic perception of the world.

The North Caucasian novel as a genre of new writing literature has been existing not too long - for an incomplete century. Despite the fact that the nature and interaction dynamics between literature and folklore was changing throughout all stages of development, though folklore has remained a major source of the literature development and the novel is still based on the epic "The Nart Sagas" - one of the oldest and most phenomenal events of the world epos. It is this novel, originally opposable to epic and myth that in the 20th century appeared in the closest interaction with these genres. According to M. Bakhtin, "the novel was becoming the only developing genre, so it more deeply, essentially, sensitively and quickly reflects the emergence of the reality itself" (Bakhtin, 1975).

In the last two decades of the 20th century in the North Caucasian literatures there have been appearing one after the other the romance myths by Kabardian writer H. Beshtokov "The Stone Age" (1985), Ossetian writers M. Bulkaty "The Seventh Campaign of Soslan Narty", (1989) and N. Dzhusoyty "Tears of Syrdon" (1987), Adyghe writers Yu. Chuyako "Legend of the Iron Wolf" (1993.), D. Koshubaev "Abrag" (1999), N. Kuyeko "The Wine of the Dead" 2002) and others eagerly sought by the reality itself.

The literary works of mythologizing authors synthesize both diverse traditions, based on the national myth, and the traditions of Russian and world literature, and discover typological convergences, intertextual connections and 'internal rollcall' with representatives of the "near abroad": with Chingiz Aitmatov, O. Chiladze, V. Astafyev, V. Belov, B. Shinkuba, A. Kim, V. Pelevin, and with European and Latin American novelists Thomas Mann, Gabriel Garcia Marquez, Alejo Carpentier, James Joyce, John Updike and others.

Clearly markable neo-mythologism paradigm of contemporary North Caucasian romance requires close research attention and interpretation. The North Caucasian literary studies include a series of articles and monographs devoted both to the creative work of individual writers, and to understanding common issues of myth, folklore and literary relationships.

The genesis of the North Caucasian romance and its structural features has been to a lesser or greater extent the subject of research attention in the monographic studies by L.A. Bekizova "From the Heroic Epos to the Romance. Artistic National Traditions and the Development of Narrative Genres in Adyghe Literatures" (Cherkessk, 1974); Yu.M. Tkhagazitova "The Adyghe Novel" (Nalchik, 1986), A.H. Musukayeva "The North Caucasian romance: Artistic and Ethnocultural Typology" (Nalchik, 1993), R.J. Fidarova "Contemporary Ossetian Romance Myth" (Makhachkala, 1997), K.N.Paranuk "Mythopoetics and Worldview in the Modern Adyghe Romance" (Maikop, 2006), M.H. Khakuasheva "Literary Archetypes in Adyghe Writers' Works" (Nalchik, 2007). Issues of literary and folk relationships and Adyghe mythology are studied in the works by U.B. Dalgat, A.I. Aliyeva, Z. and M. Kumakhovy, A. Gutov, Sh. Hut, A.T. Shortanov, M.I. Mizhaev.

However, at present there is no summary work which considers artistic features of the North Caucasian romancemyth as a complex and its typological connection with Western European and Latin American literature. That is what caused the relevance and choice of theme of this work.

\section{Research Methods}

Neo-mythologism of the 20th century, which is characterized by the synthesis of diverse traditions and the revival of underlying structures and mechanisms in the author's myth-making, requires synthetic approach to the problem of genetic continuity and typological correspondences from the researcher. Accordingly, to analyze the problem of myth, folklore and literary relationships and to identify philosophical and psychological aspects of the myth-making problem we follow not only folklore and literary aspects, but also achievements of the psychoanalytical, structural, semiotic and genre approaches. This approach allows identifying the implicit mythologism of author's certain images and motifs, to differentiate levels of mythopoetics, to delineate manifestation of mythological and folklore, to reveal the process of their interaction in the author's text.

When analyzing the characteristics of the neo-mythologism of the North Caucasian romance myth in the wider context of national and world literature, we also relied on the synchronic and diachronic research methods that identify typological convergence and commonality of literary processes and phenomena under study.

The methodological and theoretical bases of the article are the works of philosophical, cultural and philological character, those by M. Bakhtin, V. Vinogradov, G. Gachev, I. llyin, Yu. Lotman, A. Potebnya, G. Fedotov, P. Florenskyy; works of leading scholars of mythology and folklore such as S.S. Averintsev, V.M. Gatsak, U.B. Dalgat, Claude Levi- 
Strauss, J. Campbell, A.F. Losev, F.Kh. Cessidy, E.M. Meletinskyy, V.Ya. Propp, V. N. Toporov, E. Taylor, M. Eliade, C.G. Jung; works of North Caucasian research scientists - A. Aliyeva, A. Gadagatl, G. Gamzatov, A. Gutov, Z. Dzhapua, Sh. Inal-Ip, S.A. Zukhba, U. Panesh, Sh. Salakay, M. Khakuasheva, R. Fidarova, Sh. Khut, K. Shazzo A. Shortanov, Yu. Tkhagazitov.

\section{Results and Discussion}

Myth is ontological in nature and involves literature and philosophical thought because of its ambiguity. Italian scholar of the eighteenth century Giambattista Vico, creating the first philosophy of myth ("New Science") and anticipating the major trends in the development of mythological science, presented the history of civilization in the form of a cyclic process: the divine, the heroic and the human epochs express childhood, teenage and mature state of society and the common mind.

"The history of world literature according to N. Frye's concept is understood as circulating in an endless circle: the literature is first separated from the myth, developing its own, historically determined modes, but eventually returns to the myth again" (referring to the work of modernist writers).

In the 19th century there appeared linguistic concepts by M. Muller, Anthropological School (E. Taylor, E. Lang et al.), representatives of the "philosophy of life" (F. Nietzsche, H. Bergson and others) introduced new "shades" and corrections to the myth interpretation.

From the very beginning of the 20th century a rapid process of "remythologization" of myth began. There was an even greater number of schools, trends and theories that can be reduced, in total, to the "structuralism" (C. Levi-Strauss, R. Barthes), "ritualism and functionalism" (J. Frazer, B. Malinowski), the French sociological school (E. Durkheim, L. Levy-Bruhl); symbolic theories (E. Cassirer), analytical psychology (S. Freud, C. Jung, J. Campbell, M. Eliade).

Neo-mythologism in the Western literary studies traditionally correlates with postmodernism and magical realism (Magic realism. An Anthology, 1980). Problems of postmodernism, mythologism, magical realism are studied in the works of western mythologists and literary critics I.H. Hassan (Hassan, 1987), N. Frye (Frye, 1976), J. Frank (Frank, 1963), C. Levi-Strauss (Levi-Strauss, 1964,) R. Barthes (Barthes R. 1957), E. Cassirer (Cassirer, 1947), R. Weimann (Weimann, 1967), J. Campbell, A. Taylor, M. Eliade, C. G. Jung and others. For the first time the term "postmodernism" was coined in relation to the literature by Ihab $\mathrm{H}$. Hassan, who formulated a classification of post-modernism characteristics.

The works of F. Kafka, J. Joyce, T. Mann, J.-L. Borges, S. Dali, A. Artaud, A. Camus, J.-P. Sartre can serve obvious examples of actualization of "neo-mythological consciousness".

As for the "magic realism", which is determined in line with the work of G. Marquez, A. Carpentier, M. Asturias and others, the essence of this phenomenon and the different concepts are studied by the German art critic Franz Roh, the Canadian researcher Jeffrey Hancock, the American art critic Aranson, Russian literary critics S. Mamontov, A. Kofman, A. Terterian and others.

Mythologism in the literature (according to S. S. Averintsev) is a typological phenomenon. Neo-mythologism was updated in the North Caucasian literatures and, above all, in the genre of the novel in the 80-90-ies of the 20th century. The myth strongly invaded into the semantic and structural field of the North Caucasian romance having enriched its poetics and determined certain transformations in style, plot structure, image creation, genre modifications.

The novels of Ossetian writers N. Dzhusoyty "Tears of Syrdon" and M. Bulkaty "The Seventh Campaign of Soslan Narty", Kabardian writer H. Beshtokov "The Stone Age", Adyghe writers N. Kuyeko "The Wine of the Dead", Yu. Chuyako "Legend of the Iron Wolf" (1993), D. Koshubaev "Abrag" are distinguished by a wide variation in mythologism types, the presence of ancient archetypes and mythologems, the usage of a variety of methods and techniques of mythologizing.

In the study of the problem of myth-making we differentiate two things: in the first case mythologism is an interpretation and transformation of the original myth plot in the author's text; in the second case it refers to creating own myth in the text or the text modeling as a myth.

The novel in verse "The Stone Age" by a Kabardian writer Habas Beshtokov (1985) was the first experience of the bright and talented myth-making, not only in the Circassian literature (Kabardian, Adyghe, Chercessian), but in all of North Caucasian literatures.

$\mathrm{H}$. Beshtokov came back to a distant era of the Stone Age and made an attempt of artistic representation of a person at an early stage of development of the society, his way of life, attitude and world perception. As the main methods of mythologizing the author used those associated with the most ancient mythological notions - totemism, fetishism, animism. Through the image of the novel protagonis Anu, $\mathrm{H}$. Beshtokov vividly and expressively conveyed the attitude and world perception of an ancient man, just starting to peer curiously into the world around and cognize it.

Created in a novel the space-time continuum is regulated to the core, everything is animate here; space is living and breathing, representing a single cosmic body. However, some space loci are heterogeneous, for example space of 
totem animals, the Black bull and the Eagle are described in positive tones, they are normalized and harmonized. And, on the contrary, the space of the militant tribes of Dorei and Eminei represent the chaotic, irregular, unstable space.

The category of time is not only mythologized in the novel: the author creates the mythological image of the time itself. In the novel, such categories of time as a 'reversible time', 'irreversible time', 'forbidden time', 'abstract time', 'mythological time' are implemented.

In the world model depicted in the novel, a 'visible' archetypal structure of mythoepic world model is traced: its graduation is represented in the form of the world of people living on the earth; the souls of those at the point of death go to the 'distant (mythical country)'. The world of higher beings in the novel is presented by totem animals (the Black Bull, the Eagle) who were worshiped by ancient people at the depicted stage of human development. However, in the context the individual echoes of later mythic thinking elements are observed, for example, the Dorei's cave is compared with a stone hell. Such an organic symbiosis of mythological and literary and art consciousness provides a unique style of Beshtokov, forms mythopoetical world of the novel.

Poetics of mythologizing by $\mathrm{H}$. Beshtokov has much in common with the postmodern one. In particular, it is shown in tragically ironic paraphrase of traditional archetypes and motifs, in a paradoxical construction of phrases and creating bizarre images and situations:

The river flows into the sky.

The trees are bathing, standing knee-deep

In water.

Fish are sitting on the branches,

Speaking, sunbathing on the sun (Beshtokov 2005).

Thus, H. Beshtokov in "The Stone Age" creates his own, author's myth in which the literary consciousness interacts intricately with the mythoephic one. Based on the features of mythological thinking, animistic, totemic, fetishistic representations, the author, at the same time, creates his own myth of humanity at one of the earliest stages of development. In parallel, archetypal motifs and patterns typical of the national tradition are implicitly present in the context of the novel

Romances of the famous Ossetian writers, N. Dzhusoyty "Tears of Syrdon" and M. Bulkaty "The Seventh Campaign of Soslan Narty" were the first striking examples of myth-making in the Ossetian literature of the 80-ies of the 20th century. In search of answers to the burning questions of the day, these writers, paradoxically, turn to the myth, its ontology, its universal meaning and artistic features. Mikhail Bulkaty, having published his talented novel "The Seventh Campaign of Soslan Narty" in Russian in 1989, became, along with H. Beshtokov, 'a pioneer' not only in Ossetian, but also in the whole North Caucasian literature in terms of myth-making development.

Speaking about the features of the romance myth genre modification, an Ossetian literary scholar R. J. Fidarova said: "... the mythological and the historical smoothly 'ingrow' one in another, determine each other, in some way maintain one another. And therefore distinguishing between the romance myth types according to the nature of mythical historicizing, on the one hand, and mythologizing historical, on the other hand, is logically justified. In this case it is due to the nature of the genre: the romance myth is carefully looking for the intrinsic relation of the particular case, the phenomenon with the general laws of life" (Fidarova, 1997).

The space-time of M. Bulkaty's novel is the space-time of myth, where mythological and historical origins are fancifully combined and intertwined. The author creates mythopoetical chronotope, in which the model of the universe has a three-member structure: the afterlife (consisting of heaven and hell), the subsolar world where people live, and the Third world - the country of the Dalimons (devils in the Ossetian mythology). The researchers noted that the ternary system of world order is anchored in the Scythian culture. G. Dumézil in particular, says: "... both in the legends of the ancient Scythians and in the epic tales of modern Ossetians one can find out the distinct remnants of a ternary ideology" (Dumézil, 1976).

The Third world is governed by Chelahsartag and Dzatsu, masters of the Dalims. Representatives of different social and historical periods coexist here, and there is no division of time into the past, present and future. In the Third world Chelahsartag conducts an experiment on the creation of a new generation of people deprived of memory, conscience, knowledge of the past, free from heavy thoughts due to slave labor.

In the novel there unfolds a mythological story, appealing to a cosmogonic myth and narrating about the struggle for liberation from the captivity of Hurzarin - the golden Sun Mother, Earth Mother and the Universe, kidnapped by the dark forces. Accordingly, in the narrative of the novel the meta conflict is revealed, this conflict is very characteristic of myth mentality: the struggle between good and evil, projected on the specific situation of confrontation of the famous Nart 
warrior, Soslan, and the ruler of the Third world, Chelahsartag. Soslan is one of the central characters of Nartiada, known for his bravery, fearlessness, this is the culture hero who has made a lot of feats for the benefit of his compatriots. As the researchers of the Nart epos V. Abaev, G. Dumézil, Sh. Salakaya, A. Gadagatl and others repeatedly pointed out, Soslan is a solar character, his image is associated with solar myths, and his birth, life and deeds are somehow associated with fire.

Soslan according to the Ossetian version of Nartiada was married to the daughter of Hurzarin Atsyruhs, it is not surprising that Soslan was one of the first who went in search of Hurzarin. The famous epic hero is accompanied by heroes of Ossetian historical songs Chermen Tlatov (a representative of the feudal era) and Khazbi Alikov (a fighter for national freedom of the Ossetians in the 19th century).

The author of the novel creates the space-time continuum in which the epic heroes of different stages (Soslan, Uruzmag, Hamits, Batradz, Shatanaya, Dzylat), mythological deities (the golden Sun Mother Hurzarin, lord of the underworld Barastyr), demonic beings - the Dalimons and fictional and mythological characters (Dzatsu, mythical blacksmiths Tserekk and Bidas) and particular historical figures glorified in folk songs (Chermen Tlatov, Khazbi Alikov) simultaneously coexist. Ossetian pantheon is widely represented in mythopoetic space of the novel: Uastyrdzhi (or Wastyrdži) - the patron of travelers, Aefsati - the god of wild animals, Kar and Karaf - the gods of cold and frost, Safa the god of the hearth, hearth chains and others.

Image system in the novel is complex, polyphonic. Archetypes and mythologems are represented at the heart of the central images of the characters. For example, such basic archetype, as the archetype of the Great Mother, is realized in the female characters of Hurzarin and Shatanaya (Satanaya). It is known that the "Great Mother" archetype (Mother Goddess, Earth Mother, Foremother) dates back to the ancient cosmogonic representations of the cosmos birth from a disordered chaos, where the image of the mother goddess is associated with precultural, natural state. This archetype is personified in the image of Hurzarin as her heavenly incarnation, symbolizing the source of vitality and immortality. It implements the basic function of Mother Goddess - its creative function: participation in the creation of the world and all things on earth. "The whole world is my child. I breastfeed it, "- says Hurzarin (Bulkaty, 1989). The image of Shatanaya (Satanya) is also archetypal, which is traditionally associated with the mother of all the Narts (and particularly of Soslan). It personifies the earthly incarnation of the Great mother. And she is the earthly incarnation. The most common for Nart epos warrior archetype is realized in the images of Soslan, Batradz, Uruzmag, Hamyts, Akhsar, Ahsartag, Batradz.

The protagonist of the novel is Soslan, his image realizes another basic archetype - a culture hero. From the Nart epos, the widely accepted virtually by all the peoples of the North Caucasus, it is known that the Narts owe much to this hero who brought them the fire, grape seeds, brought them back millet seeds, etc. The culture hero, as a rule, creates, organizes, and develops the semantic space of culture, but his image is binary, and combines both constructive and destructive origins. This is due to the fact that the image of a culture hero existed in indissoluble unity with its antipode the trickster in the most archaic representations. The trickster is a violator of established laws and traditions, his image embodies the destructive function. In the novel by M. Bulkaty the image of the trickster is personified in Chelahsartag the leader of the Third world. Soslan and Chelahsartag are rivals at all times, their conflict was beginning yet in earthly life when Chelahsartag, while still in the Nart country kidnapped Soslan's wife Atsyruhs during his absence and locked her in his castle. But the Narts destroyed his fortress and returned Atsyruhs. The conflict of the two eternal rivals, Soslan and Chelahsartag, continued in the Third world as well.

Chelahsarag and Soslan are polar opposites, representing the forces of darkness and light in the abstract and in the concrete senses. Soslan is presented in the novel not only as famous for his noble deeds of the epic hero - this is an intelligent character, not devoid of psychological expression. The deep meaningful reflections on the meaning of life, good and evil, the essence of human existence are inherent in him.

The author of the novel widely uses different figurative means and techniques of mythologizing, in particular, lycanthropy (the Dalimons), duplicity, duplication. For example, all Nart heroes who went to the Third world in search of Hurzarin, receive new names: Chelahsartag - Lagza, Ahsartag -Santar, Hamits - Dzoko, Batradz - Dzors, Gabat Kanukov - Tsandi and so on. Such amazing mythical obects as fyd rohganan durr - a stone, sitting on which one forgot all the trouble, the hair-bridge through which souls crossed to get to the next world, wonderful armor and helmet to help the owner at his first call and others are mentioned in the mythopoetic layer of the novel.

But the most significant of the mythopoetic images created by the author is the image of the mythical lake of milk, which has conceptual meaning for the expression of the philosophical ideas of the entire novel. This image is a symbol of evil, one of the main attributes created by Chelahsartag and Dzatsu, a monstrous system of total suppression of the individual. A person having swum in the milk lake loses his memory, forgets about the past, he becomes immortal and eternal bliss and becomes, in fact, a mankurt. As the author writes, Chelahsartag and Dzatsu "kept minds of their fellow 
citizens on a leash", and Hurzarin "has contributed to the confusion of their souls with glow golden rays", fired the minds of the people involved into continuous work. Chelahsartag wants to marry Hurzarin, in order to fly with her to heaven after that, so people would say looking at them not "the sun has risen", but "the sun has risen with Chelahsartag". After the apparent rejection by Hurzarin, Chelahsartag initiated her capture.

Through a well-known meta conflict of good and evil, projected on a particular situation arising in connection with the abduction of the "golden mother" Hurzarin, the author creates his own myth, in which he is conducting his own artistic research of the nature of good and evil. The narrative of the novel clearly marks vitality and diversity of the evil which grows through all generations of all time. For example, "the Dalimons see their father Lagza in the image of the creator of the Third world, Soslan recognizes Hyz's son Chelahsartag in him, and he reminds his uncle Dhaka to Chermen" (Alborova, 2013). So gradually the author's idea of the identity of the Third world and the human world, and the eternal conflict between good and evil in this world of duality is realized. Yet the end of the romance myth by M. Bulkaty demonstrates the triumph of the forces of light and the victory of good over evil: the Narts led by Soslan rescue Hurzarin from captivity to let her continue covering all realms with her loving mother's light. According to the author, it is within her power to destruct evil and crush milk lakes and other instruments of suppression of human nature created in the Third world. This is the essence of the author's philosophical conception. The reviews rightly note that M. Bulkaty "developed his own unique style, preserving the link with tradition ..." (Bocharov, 1978).

Speaking about the type of mythologizing of M. Bulkaty in the novel "The Seventh Campaign of Soslan Narty", we consider the opinion of R. J. Fidarova, a literary scholar, completely fair, who writes: "The North Caucasian mythoephic thinking most clearly manifesting in the Nart epos and transforming in the process of literary and folk interaction served as the base for the formation of the genetic and spiritual origins of the Ossetian romance myth, which had absorbed the experience of other, more mature literatures, romance myth, creatively using novelistic myth thinking tradition of T. Mann - the originality of the organization of Space-Time in the romance myth as the major factor of its genre validity and structure"(Fidarova, 1997).

The novel by a young Adyghe writer D. Koshubaev "Abrag" (1999) bears resemblance with the novel by M. Bulkaty according to the type of mythologizing. Likewise the Ossetian writer, in the novel "Abrag" D. Koshubaev appeals to the subjects of the Nart epos, on the basis of which the author creates his own myth, sometimes turning into a parody, travesty, and even anti-myth. The action takes place in the "beautiful emerald golden city", Abrag, in which "all were in plenty", but which did not stand the test of God's love and was sunk.

In the novel, which consists of four parts, the first and third parts of the story are narrated on behalf of Alberta Krymov, talking about his childhood years spent in Abrag (the first part), his return to his hometown as an adult in order to write a book about it (the third part). The second part, the core component of the plot, "a novel in the novel", tells the story of the Narts and represents a kind of excursion into the mythoephic past in search of ideal heroes.

As the Adyghe literary scholars note, "the use and interpretation by the author of the myth-folklore material in different parts of the novel varies widely from traditional to postmodern techniques and differs greatly from all previous reminiscences of this kind in the Adyghe literature" (Paranuk, 2006). The artistic retrospective of the Nart epos is carried out in the novel, according to the author, "with a knowing smile". The young author is interested not so much in loud actions of famous epic heroes, Sosruko, Badynoko, Batraz, Ashemez and others, as motives of their actions. The author presents the Narts in the vast majority as jealous, cunning, selfish people. An essential feature of the style of the novel is the presence of irony, so characteristic of postmodern poetics of mythologizing.

In the novel, the pantheon of Adyghe gods is widely represented: the supreme almighty Tkha standing over all (alias Uashho), Tlepsh - a blacksmith deity, Thagoledzh - the god of agriculture, Psatha - the god of soul, Sozrash - the god of prosperity, Mazathe - the god of forests, Amysh - the god of cattle-breeding. But their depiction acquires more often a humorous connotation, sometimes rolling in irony. The irony, a characteristic element of poetics of postmodern mythologizing, is inherent in all parts of the novel.

Part Three "Hagrey" describing the pictures of life of the modern Adygeyan city of Abrag begins with the appearance in it of a "mysterious trinity": Dissector, Executioner and Apologus, "sent to the city of Abrag, according to the disposition of God and Providence, .... to solve this Sodom and Gomorrah task at hand" (Koshubaev, 2004). The content of this part leads to the conclusion that a century of heroes, strong, courageous, great in all their manifestations has sunk into oblivion. 'Ordinary people' came in their place, steeped in sin and deception: the light of Medicine, a psychiatrist Psathov (translated from Adyghe as "God of the soul"), a composer Dzheguakov (translated from Adyghe as "a songwriter, organizer of the wedding revels"), an artist Persikov, a researcher of the Adygeyan etiquette Habzikov (translated from Adyghe as "Zakonnikov" (implying "legalist')) and others, imagining themselves geniuses and righteous men of Abrag. Their meaningful names symbolize the author's bitter smile at the fact that the human malices are still tenacious - envy, arrogance, intolerance of another's superiority and so on. The search for truly righteous men in Abrag 
is in vain, and the city is being flooded, and there appears the emerald lake in its place. The situation portrayed by the author and some of the characters resembles the novel by Mikhail Bulgakov "The Master and Margarita". There is a grotesquely fantastic satirical nature, exposing flaws and contradictions of life in both novels.

Mythopoetic image creation in "Abrag" recalls M. Bulkaty's novel "The Seventh Campaign of Soslan Narty". Heroes live and act in the real physical world and at the same time manifest themselves in the world of shadows, or vice versa, the shadow of the departed visit the world of the living. Such is, for example, a grandmother Barymbuh passing from the world of the dead to the living world, "waving her "membranous wings"; Dissector, Executioner and Apologus, eyewitnesses of Sodom and Gomorrah, in whose images one can see parallels with biblical motifs. Their bodies often "seem asomatous" and Apologus - "an angel with a human heart" - is able to fly, to open a door with "his asomatous arm. The methods of duplication, duality, mirroring are also frequently used here. For example, Krymov recognizes "a woman for the ages" in a random friend from Abrag, Ahumida, whom he met in the temple of Amon Ra, when he served there as a priest. Smoke, fog, dreams, recognition the same people in different guises through a veil of times - these are those artistic devices that create the mythological context of the novel.

The end of the novel is also mythologized, which describes the sinking of Abrag and goes back to the eschatological myth.

Thus, the nature of myth-making by D. Koshubaev in "Abrag" is defined by the presence of two types of mythologizing: if there is the realization of significantly transformed and modernized mythoephic material contaminated with universal motifs other mythological traditions in the second part devoted to Nartiada, then in conjunction with other parts the entire novel is modeled according to the laws of the myth.

According to the type and methods of mythologizing, myth-making by D. Koshubaev in the novel "Abrag" relates primarily to Western European novel and postmodern aesthetics. And, despite the fact that the author of the narrative draws directly upon national mythoephic material, the principles of narrative and artistic representation of reality are indicative of the postmodern character. They include myth travesty used as the main core of the narrative; the motif of loneliness, characteristic of the protagonist (who is also the narrator) with existential consciousness, and his escape into the world of myth from ugly reality; the free development of the plot, combining diverse materials of myth and real actuality; the presence in the novel of broad intertextual relations (Bulgakov's motifs: quoting, phrases from the novel "The Master and Margarita" by M. Bulgakov, images of Dissector, Executioner, Apologus, dating back to biblical motifs, motifs of the eastern mythology: Amon Ra); unrestricted spontaneous act of myth-making: images of citizens of Abrag: Habzikov, Suretov, Dzheguakov and others; apocalyptic motif expressed in the sinking of the city of Abrag; pervasive and all-encompassing irony, dominant in the novel as the main element.

All this together allows us to conclude that the novel "Abrag" by D. Koshubaev corresponds to the postmodern poetics, which in this case is not an expression of opposition, but the continuation of Western European modernism represented by James Joyce ("Ulysses", "Finnegan's Wake"), or by American author John Updike ("The Centaur"). The analogy with the latter novel can be made in terms of judgment by the authors the sense of existence and the ways of realization of the individual, especially the plot, the essence of which is the hero's escape as a form of release and gaining freedom.

A characteristic feature of the myth-making by H. Beshtokov, M. Bulkaty and D. Koshubaev is the connection with the mythoepic tradition, which can be defined as a travesty, the myth travestying (D. Koshubaev), the creation of the author's myth ( $\mathrm{H}$. Beshtokov, M. Bulkaty), and their novels are defined within postmodernism.

The nature and mythologizing devices of another Adyghe writer, Nalbiy Kuyeko, differ from myth-making of previous authors and relate to such world literary school as 'magical realism'.

E. M. Meletinskyy pointed out that "the mythologism in the novel of the 20th century functions in a very wide area, not reducible to western European modernism of the 20s-30s in the narrow sense of the term" (Meletinskyy, 2000). He urged "while studying the roots of the phenomenon of mythologizing in the 20th century "particularly to take into account such things as a desire for one reason or another to link the present with the past in a single stream, either for the detection of a single metaphysical nature (J. Joyce), or for reliance on the traditions of European humanistic thought and classical morality (T. Mann), or in the name of conservation and restoration of national forms of thought and creativity (Latin American and African-American writers)" (Meletinsky 2000).

The novel "The Wine of the Dead" (2002) was an outstanding phenomenon in Adyghe romance studies and has been recognized by scholars as a modern national epos. The author attempts to tell the story of his people's existence during all the years on earth using poetics and ontology of myth. The novel consists of seventeen independent short stories and it is a synthesis of a wide variety of methods and means of mythologizing, beginning with the use of certain myths and ending with total mythologization of the whole context. The author skillfully combines external and implicit methods of mythmaking in a narrative. On the one hand, he makes extensive use of images and motifs from mythoepics, 
on the other hand, he travesties them, contaminates with other elements. But it is most often a paraphrase, romantic, enthusiastic, and strikingly different from the post-modern poetics, ironic narration, for example, by D. Koshubaev. It should be noted that along with the mythological there is a wonderful, fantastic element, paired with the author's desire to find a miracle in a very common everyday reality in the infinite variety of life. The characters of N. Kuyeko feel 'the magic of life' with all their being, metaphysical characters perform transcendental flight in their souls, feel the infinity of space and time.

The wide variation in methods of mythologism, organic combination and interpenetration of realistic, mythological, fantastic elements in the novel by N. Kuyeko "The Wine of the Dead" allows one to see the similarity with such mixed type as "synthetic" mythologism taking place, particularly, in the works by G. Marquez. Novels by G. Marquez "One Hundred Years of Solitude" and N. Kuyeko "The Wine of the Dead" show a certain typological convergence.

It is known that in the 50 - 60s the poetics of mythologizing permeated both the Latin American and some African and Asian literatures. Despite the undeniable influence of Western modernism, the character of mythologism in these literatures was markedly different. For example, whereas Western European novel mythologism, as fairly observed by E. M. Meletinsky, "is not based on folk traditions", the "the archaic folk traditions and folklore and mythological consciousness, at least in vestigial form, can exist in Latin American and Afro-Asian novels side by side with contemporary intellectualism of purely European type" (Meletinskyy, 2000).

Such culture-historical situation emerged in Adyghe literatures, however, a few decades later. But they demonstrate the same, according to Meletinskyy, "co-existence and mutual penetration, sometimes amounting to organic synthesis, elements of historicism and mythologism, social realism and state of authentic folklore, the interpretation of which ranges from the essentially romantic chanting of national identity to contemporary search of repeated archetypes" (Meletinskyy, 2000).

Y. M. Thagazitov reasonably says about the possibility of certain typological similarities between the Adyghe and Latin American novel: "... of course, it is impossible to see the full compliance of development of Adyghe and Latin American novel, it is due to the specific socio-economic conditions of development of the countries with different histories and social system. But typological similarity still has its reasons: it is a typology of development stages, at which literatures of regions under analysis are. On two different turns of the historical spiral externally so different literatures 'dock' at such a commonality as the world literature of the 20th century" (Thagazitov, 1994).

A brief comparison and collation of novels by G. Marquez "One Hundred Years of Solitude" and N. Kuyeko "The Wine of the Dead" confirms the validity of these theses. In the work of these authors, despite the obvious artistic originality and creative personality (for example, the irony dominating in the novel by G. Marquez) distinct similarities in the methods and techniques of mythologizing are found.

Both G. Marquez and N. Kuyeko, reproducing realistic history of their people, widely rest upon the people's mental outlook, native folklore and mythology. The story of the Buendia family in the novel "One Hundred Years of Solitude" and the story of the Hatkoeses family in the novel "The Wine of the Dead" is poured into a grand narrative about the history of the Colombian people in G. Marquez's novel and history of the Circassians in N. Kuyeko's novel. G. Marquez recreates the story of Colombia for a hundred years (since the forties of the 19th century to the thirties of the 20th century) in the epic "One Hundred Years of Solitude", reflecting the history of six generations of the Buendias. N. Kuyeko implements the same idea in the novel "The Wine of the Dead", and the Hatkoeses' history is also mythologized, traced from ancient times to the present.

Both G. Marquez and N. Kuyeko "create comprehensive, total synthetic novels according to the genre, in which realistic and mythological elements are interwoven, forming intricate multidimensional chronotopes characteristic of magical realism" (Paranuk, 2013).

G. Marquez, describing the story of the small town of Macondo in the novel "One Hundred Years of Solitude", creates a very distinct "model of the world', which is both a "Colombian" and "Latin American", and, in part, "universal". Created by N. Kuyeko the space-time continuum of the novel reflects not only a national image of the world, but also blends in with the model of the universal existence.

Both G. Marquez and N. Kuyeko successfully synthesize various kinds of mythologism in their novels, from the explicit methods to the implicit ones, from the use of original myth plots to the author's mythmaking. Both writers skillfully operate with different temporal plans and often use mythologized poetics of repetitions and substitutions.

G. Marquez, emphasizing the Buendias' members belonging to the same genus, gives them not only the common features of appearance and character, but hereditary names as well. The characters take turns by reproducing the same kind of Colonel - the family patriarch, infinitely bifurcate and multiply, duplicate and reflect each other (the patriarch Jose Arcadio Buendia - José Arcadio the First - Jose Arcadio the Second, Aureliano - Aureliano the Second - Aureliano Babilonia, Ursula - Ursula Amaranta). 
The secular reflectance principle, essence duplication is a characteristic feature of mythologizing in N. Kuyeko 's novels as well, the Hatkoeses' names are often repeated in the novel: Dedera, Goschanda, Temzag, Tabarak; palindrome names are also used: Deder-Reded, Shabatnuko-Kuntabesh, Fenes-Senef.

The system of images of both novels is characterized by the presence of representatives of the infernal world, boldly striding over the line of life and death: Melquiades (in G. Marquez's novel), three-grandmothers, Lyashin (in N. Kuyeko's novel).

Common to both novels is also the mythologem of loneliness, having the conceptual meaning for the philosophical idea expression. Individual fates of the Buendías' family members, plunging into 'an abyss of solitude', are the result of alienation from their family, retreat from the moral laws of the family. The mythologem of loneliness is very important in the novel "The Wine of the Dead" by N. Kuyeko. Once fearless warriors, ready to serve their motherland, dropping out of the usual life track, they feel uncomfortable in civilian life, out of business.

Both novels are characterized by frankly eschatological end, the town of Macondo is swept away from the earth by the storm (Marquez, 1989), and the Hatkoeses' family is gradually fading, and the once fearless warriors leave this life one after another, unable to adjust to civilian life, creative work. But along with the pessimistic end of the historical plane of the narrative an optimistic version is given at the end of the novel, the final mythopoetical plane. The end of the novel describes the death of the God-man Tlepsh, a decent of the Hatkoeses, and the simultaneous birth of his son, "looking like the sun" (Kuyeko, 2002). The birth of the solar character, the inverse image of the Narts, carries the idea of cyclical and universal repetition, transforming the eschatological situation into the cosmogonic one.

Thus, we can conclude that the nature and types of mythologizing in the novels by G. Marquez "One Hundred Years of Solitude" and N. Kuyeko "The Wine of the Dead" bear a lot of resemblance, allowing to refer them to mixed, "synthetic" mythologism, characteristic of magical realism.

Mythmaking of another Adyghe writer, Yunus Chuyako, relates to the first type of mythologizing when the author uses the original myth plot and partially reconstructs it. In the novel "The Legend of the Iron Wolf" with rich folklore and mythological context, the myth of the Iron Wolf takes the conceptual meaning for the text artistic structuring and "unfolds in the contents" in the course of the story, defining semantic and structural integrity of the text. An organic fusion and interweaving of realistic and mythological elements, complex space-time chronotope characteristic of the romance myth, take place here too.

In total, the artistic image of the world, reproduced in the romance myths by the authors under consideration, has a pronounced mythopoetical character and reflects all the basic spiritual, moral and social paradigms of national existence, inclining to the universal model, to the entire universe.

\section{Summary}

The analysis of the modern North Caucasian romance was conducted to indicate in it the presence of deep folk and mythological context. The nature of the mythologism of the North Caucasian romance can be defined as neomythologism, which has become a remarkable phenomenon for the world literary process of the 20th century.

The North Caucasian romance of the last three decades shows examples of surprising combinations, folk myths rethinking coupled with complex modifications of artistic time, the inner monologue and other signs of narration of the 20th century.

Studies of the Caucasian literary scholars urge that national literatures do not keep aloof; they are increasingly involved in the world literary process, mutually enriching each other. The romance myth, ritual and mythological novel, popular in Western literature are becoming very attractive for national literatures.

This is proved by the paradigm of neo-mythologism clearly marked in the novels by Ossetian writers N. Dzhusoyty "Tears of Syrdon", M. Bulkaty "The Seventh Campaign of Soslan Narty", Kabardian writer H. Beshtokov "The Stone Age", Adyghe writers N. Kuyeko "The Wine of the Dead", Yu. Chuyako "The Legend of the Iron Wolf", D. Koshubaev "Abrag" and the others.

These novels mark the trend to modernize classical mythology which is common for the world literature of the 20th century. They demonstrate re-mythologizing, mythopoeic "re-creation of the ancient stories", and finally, myth-making, the creation of new myths that "met the aspirations of life creating various literatures" (Sarukhanyan, 2002).

New myth poetics "is not only a mythological way of literary artistic reconstruction, but also an enhanced myth ontological reflection. If the typification is used in the literature to form artistic images and motifs, then in the course of neo-mythologism ... the arhe-typification is actively used" (Hakuasheva 2007). Such methods of organizing the artistic text as intertextuality, allusion, reminiscence, code, symbol, myth, and archetype are characteristic of neo-mythologism.

Mythopoetic model of the world, created in the romance myth by the writers of the North Caucasus, displays the 
national image of the world and at the same time tends to be the entire universe.

\section{Conclusions}

1. In the North Caucasian novel of the last three decades the neo-mythologism paradigm is distinctively marked.

2. Re-mythologizing of the North Caucasian novel and the modernization of classical mythology at the turn of XX-XXI centuries stipulated its definite transformation that has led to the expansion and deepening of their perspectives and enrichment of the genre and stylistic forms.

3. Creative methods, style trends, in which neo-mythologism is in demand, are quite diverse: from the realistic novel with the elements of mythologism to philosophical and mythological novel, postmodern romance myth.

4. In the 80-90's a new genre modification - a romance myth - appeared in the North Caucasian literatures.

5. Mythopoetics had a significant impact on the range of problems and conflict of the North Caucasian novel and led to the specific features of plot, image making and artistic structure.

6. Modern North Caucasian romance myth is a complex and multi-dimensional artistic and aesthetic system, which, on the one hand, is based on the national folklore and mythological sources, on the other hand, acquires and reflects the traditions of world literature and contemporary trends of its development.

7. Neo-mythologism, new myth-making of contemporary authors is expressed both in the creation of new myths and in re-mythologization (new character of mythoepic tradition assimilation) and demythologizing (the travesty, the classic myth parodying, and the anti-myth creation). In the novels by M. Bulkaty, N. Kuyeko, $\mathrm{H}$. Beshtokov, D. Koshubaev a world is created in which any possible transformations-conversions are possible and which is built according to the laws of the myth.

8. Neo-mythologism of the North Caucasian contemporary novel and the variation of different ways of mythologizing suggests typological convergences not only in 'near abroad' literatures, but also in the world literature, in particular the Western European, Latin American literatures.

\section{References}

Alborova, T.A. (2013). Mif i realnost v romane Mihaila Bulkaty "Sedmoy pohod Soslana Narty" [Myth and Reality in Mikhail Bulkaty's novel "The Seventh Campaign of Soslan Narty"]. Vestnik Adygejskogo gosudarstvennogo universiteta. Ser. Filologija $i$ iskusstvovedenie. Majkop. Vyp.2. (pp.138-141). [in Russian].

Bahtin, M.M. (1975). Voprosy literatury i jestetiki [Literature and Aesthetics Issues]. - Moscow. (p. 451) [in Russian].

Bart, R. (1989). Izbrannye raboty: Semiotika. Pojetika [Selected Works: Semiotics. Poetics] - Moscow. (P. 616). [in Russian].

Barthes, R. (1957). Le mythe d' aujourdhui. Mythologies. - Paris. (pp.47-50).

Beshtokov, H.K. (2005). Kamennyj vek: roman-mif [The Stone Age: Romance Myth]. Literaturnaja Kabardino-Balkarija. - Nalchik. No.5. (pp. 58-116). [in Russian].

Bocharov, A. (1978). Zvezda Jemrajna i skorlupa obydennosti [Emraan's Star and the Shell of Routine]. Literaturnaja gazeta 26 aprelya. [in Russian].

Bulkaty, M. (1989). Sedmoy pokhod Soslana Narty ["The Seventh Campaign of Soslan Narty"]. - Moscow: Sov. pisatel. (p. 154) [in Russian].

Cassirer, E. (1947). An Essay of Man. - New Haven. (pp. 21-22).

Chujako, Ju. G. (1993). Skazanie o Zheleznom Volke [The Legend of the Iron Wolf] - Maikop. (P.384) [in Russian].

Dumézil, G.. (1976). Osetinskyy epos i mifologiya [Ossetian Epics and Mythology]. - Moscow (p. 155). [in Russian].

Fidarova, R. Ja. (1997). Sovremennyy osetinskyy roman-mif. Genezis. Struktura. Zhanrovye osobennosti [Contemporary Osettian Romance Myth. Genesis. Structure. Genre Peculiarities]: Abstract of doctoral thesis. ... D.Phil. - Makhachkala. (pp. 18; 45) [in Russian].

Frank. (1963). Spatial Form in Modern Literature. The Widening Cyre New Brunswick. - New York. P. 3-62.

Frye, N. (1976). The Secular Scripture. A Study of the Structure of Romance. - Cambridge (Mass.), Harvard University Press, (pp. 2122).

Hakuasheva, M.A. (2007). Literaturnye arhetipy v hudozhestvennyh proizvedenijah adygskih pisatelej [Literary Archetypes in Works of Art by Adyghe Writers.] - Nalchik. (p. 343) [in Russian].

Hancock, G. (Ed.) (1980). Magic Realism: An Anthology edited and with an Introduction. - Toronto: Aya Press. (P.200).

Hassan, I. (1987). The Postmodern Turn. Essays on Postmodern Theory and Culture. - Ohio: Ohio State: Univ. Press. (pp. 17-39).

Koshubaev, D.P. (2004). Abrag. - Nalchik: Elbrus. (p. 80). [in Russian].

Kuyeko, N.Ju. (2002). Vino mertvyh [The Wine of the Dead] - Maikop. (p. 294) [in Russian].

Levi-Strauss, C. (1964). Le cru et le cuit. Mythologiques. - Paris. (p.30).

Márquez, G. (1989). Sto let odinochestva [One Hundred Years of Solitude. - Moscow: Hudozh. lit. (P.410) [in Russian].

Meletinskyy, E.M. (2000). Poetika mifa [Myth Poetics] - Moscow: Vostochnaja literatura. (pp. 297; 370-372; 365) [in Russian]. 
Paranuk, K.N. (2006). Mifopoetika i hudozhestvennyy obraz mira v sovremennom adygskom romane [Mythopoetics and Artistic Image in the Contemporary Adyghe Romance] - Maikop. (p. 66). [in Russian].

Paranuk, K.N. (2013). Osobennosti mifologizma v romanah G. Márqueza «Sto let odinochestva» i N. Kueka «Vino mertvyh» [Mythologism Peculiarities in novels by G. Marquez's "One Hundred Years of Solitude" and N. Kuyeko's "The Wine of the Dead"]. Vestnik Adygejskogo gosudarstvennogo universiteta. Ser. Filologija i iskusstvovedenie. Vyp.2.- Maikop. (pp.175-182). [in Russian].

Saruhanjan, A.P. (2002). Novoe mifotvorchestvo: W. B. Yates i J. Joyce. [New Myth-making: W. B. Yates and J. Joyce]. Hudozhestvennye orientiry zarubezhnoj literatury XX veka. - Moscow: IMLI RAN. (pp. 284-305). [in Russian].

Thagazitov, Ju. M. (1996). Evolyutsiya hudozhestvennogo soznaniya adygov: Opyt teoreticheskoy istorii: epos, literatura, roman [The Evolution of Artistic Consciousness of the Circassians. Experience, Theoretical History: Epos, Literature, Romance]. - Nalchik. (p. 187) [in Russian].

Weimann, R. (1967). Literaturwissenschaft und Mythologie. - Berlin. Heft 2. (S. 260-302). 